\title{
Internationalizing the Undergraduate Curriculum
}

\author{
Opening Commentary
}

\author{
-Benjamin R. Barber, \\ University of Maryland
}

$\mathrm{T}^{\mathrm{h}}$ he excellent papers in this symposium warrant our close attention for the cardinal reason that they teach citizenship in the global world. They arm us with ideas, concrete techniques, and specialized skill sets to reach this goal. The simple importance of learning to function well in a global society belies the complexity of achieving it. These papers give us tools as well as provide motivation to confront this challenge.

The work here looks at the dynamics of global change, but particularly emphasizes comparative inquiry and the recognition and appreciation of difference. The examination of difference is essential for a nuanced understanding of globalization. But this is only a beginning. A focus on difference alone can only produce a static view. Global themes today are marked as much by change as by difference. The world is changing in ways that make it impossible to understand it without new ideas, new perspectives, new modes of inquiry and levels of curiosity. We must understand the message in these papers in terms of enriching modes of inquiry and dynamic processes of global interaction, as well as in terms of the appreciation of difference in language, culture, geography, and politics.

And more, these papers, and the issues that motivate them, are of consequence for understanding the politics of our domestic communities as much as for understanding communities of distance. "Getting it" about internationalizing is essential for "getting it" about localism as well. We live in local worlds of interdependence as well as global ones. The papers to follow make a rich contribution to a multi-layered set of issues and are part of an important conversation about difference, change, and global understanding.

To be of relevance, political science needs to approach global politics and the issues the global context raises through a lens the insights and techniques these papers offer can help construct. It is incumbent upon the discipline as a whole to move these issues to center stage and encourage much more new work in these directions.

The following papers are a product of an APSA initiative on internationalization sponsored by the American Council on Education (ACE) with support from the Carnegie Corporation of New York. The APSA Committee on Internationalizing the Undergraduate Curriculum (Christine Ingebritsen (chair), University of Washington; Mark Cassell, Kent State University; Steven Lamy, University of Southern California; David Mason, Butler University; Pamela Martin, Carolina Coastal University; and Deborah Ward, Seton Hall University) aims to encourage political science as a discipline to think through how to teach in this new, global world. Following the individual papers, the Committee has also provided a set of learning objectives and web resources to assist faculty in devising curricula with an international focus.

\section{SYMPOSIUM AUTHORS' BIOS}

Benjamin R. Barber is the Gershon and Carol Kekst Professor of Civil Society and Distinguished University Professor at the University of Maryland, Distinguished Senior Fellow at Demos, and director, CivWorld. Among his 17 books are the classic Strong Democracy (1984), reissued in 2004 in a twentieth anniversary edition; the recent international best-seller Jihad vs. McWorld (1995, with a Post 9/11 Edition in 2001, translated into 20 languages), and Fear's Empire: War, Terrorism and Democracy (2003), also published in eight foreign editions.

Mark Cassell is associate professor of political science at Kent State University. His recent book, How Governments Privatize: The Politics of Divestment in the United States and Germany (2002), won the Charles $\mathrm{H}$. Levine Award from International Political Science Association for the best book in public policy and administration published in 2002.

Christine Ingebritsen is associate professor in the department of Scandinavian studies at the University of Washington. She is the author of The Nordic States and European Unity (1998) and co-editor of Globalization, Europeanization, and the End of Scandinavian Social Democracy? (2000) and Small States in International Relations (2006).

Steven L. Lamy is professor of international relations and director, Teaching International Relations, at the University of Southern California. His books include Contemporary International Issues: Contending Perspectives (1988) and International Relations for the
Twenty-First Century: A Rough Guide for Participants in Global Communities (forthcoming). He has also authored several book chapters, including, most recently, a case study on the Dutch in Srebrenica and a chapter on the G-8 and Human Security Issues.

Isis I. Leslie recently completed her Ph.D. in political theory at Rutgers University and has been a visiting scholar at the American Political Science Association's Centennial Center for Political Science \& Public Affairs. She is currently working on a research project entitled, "The Vicissitudes of Romanticism in America." She is teaching this spring at Georgetown University.

Pamela L. Martin is assistant professor of politics and international relations at Coastal Carolina University. She is also the director of the International and Global Studies Minor, as well as co-advisor to the Globalist Club, which has members from both South Carolina and Ecuador. Her most recent book, The Globalization of Contentious Politics: The Amazonian Indigenous Rights Movement (2003), analyzes the benefits and challenges of global processes on indigenous peoples in some of the planet's most remote areas

Deborah E. Ward is assistant professor of political science at Seton Hall University. Her areas of specialization include American Politics, Urban Policy and Development, Welfare Policy and Welfare State Development, and the Politics of Race and Ethnicity. She is the author of The White Welfare State: The Racialization of U.S. Welfare Policy (2005). 